International Conference on Education \&
$\begin{array}{r}\text { European Proceedings of } \\ \text { Educational Sciences }\end{array}$
EpICEEPSY

DOI: $10.15405 /$ epiceepsy.20111.17

$11^{\text {th }}$ ICEEPSY 2020

The International Conference on Education and Educational Psychology

\title{
ORGANIZATIONAL HAPPINESS NEW HORIZONS: HUMAN'S WORK FUTURE, EMPLOYER-BRANDING AND CHO'S-CHIEF HAPPINESS OFFICERS
}

\author{
Patrícia Araújo (a)* \\ *Corresponding author
}

(a) IPAM - Instituto Português de Administração e Marketing / Portuguese Institute of Administration and Marketing,Portugal, pattaraujo@gmail.com

\begin{abstract}
Organizational happiness is emerging as a umbrella construct for several research fields related to workplace wellbeing and organizational behaviour, and CHO's-Chief Happiness Officers is a new profession in need of exploration and research. The Future Work/Technology 2050 Global Scenarios Report highlights the need for a new social contract of workers' rights, in a transactional and global economy and to explore new ways to promote a meaningful working life: Implementing CHO's might be on path for achieving that goal. This paper explores which are the future consequences of implementing CHO's in the organizations. Futures research methods is the systematic study of possible future events and circumstances, and using the future wheel, we explore foreseeable consequences of CHO's in organizations. Ten first-order consequences emerged and exploratory inductive thematic analysis was performed. Findings suggest $\mathrm{CHO}$ 's promote inter-departmental articulation (Liaison), improve well-being at work and empowerment, develop a strong employer brand, and might build a Healing organization, but it might present challenges since it's a new profession with scarce training and it might lead to companies overloading present jobs and even trying to use CHOS as a media strategy. The need to transition to a new economics more humane, peaceful and equitable is undeniable. In 2015, world leaders agreed to 17 goals for a better world by 2030 and the 8th is 'decent work and economic growth', with ILO-International Work Organization redefining at the same time the decent work concept. CHO's represent an opportunity to rewire organizations worldwide and transform them in positive, learning and healing organizations, building meaningful jobs and sustainable labour market.
\end{abstract}

2672-8141 C 2020 Published by European Publisher.

Keywords: Organizational happiness, employer branding, occupational health psychology, future studies. 


\section{Introduction}

The future of human work is changing and, finally, work (not necessarily employment) might be a way to transcend and find purpose and meaning, instead of a torture negative meaning that it always had. Stills, there is a long way to go, with bad jobs, job insecurity, low quality of working life and many others unfair and unworthy work to be battled worldwide (Araujo, 2015).

Nevertheless, Organizational Happiness $(\mathrm{OH})$ is an emerging area of fusion between various disciplines and has emerged as a construct that recently came to unite several areas that were research separately (Fisher, 2010).

Happiness at Work is important not only for employees, but also for organizations, since organizations that care about Happiness at work and the well-being of their employees, provide an organizational climate that stimulates employee satisfaction, leading employees to perform their tasks with greater commitment, quality and creativity, promoting overall organizational success (Fisher, 2010). According to the author, enhancing $\mathrm{OH}$ should be a main goal of organizations, taking into account that organizations depend on their employees, it is necessary to keep them committed and happy.

Around the construct of $\mathrm{OH}$ and this new profession of Chief Happiness Officers there are several multidisciplinary fields, in the present moment and in the future, that we must explore and consider.

For many years, QWL- Quality of working life was a central approach, with human resources and Organizational psychologists, organizational sociologists and similar professionals occupying the vacancies that implemented occupational health approaches at work. QWL construct kept evolving and adjusting, from early simple meanings to complex view of human condition at work.

But QWL still had a narrow view of the psychological and deep meaning of humans work (Fernandes, 1996). On the other hand, organizational behaviour has studied well-being at work for almost a century, with largely explored literature and evidenced-based research.

Well-being is a complex construct which is growing in research and evolving as human life and work also evolves quickly. If, for many years well-being meant only to satisfy basic needs, we can now look from others points of view, either evaluative or even florishing (Thompson \& Marks, 2008).

As the authors explain "Flourishing accounts emphasise ways of living - literally 'living well"” or living the 'good life' - in which people are able to reach their full potential (.,..While) Evaluative, accounts are those that identify well-being with individuals' subjective appraisals of aspects of their life and how it is going" (p. 9). For the authors, well-being is dynamic, as the model showed in Figure 1. 


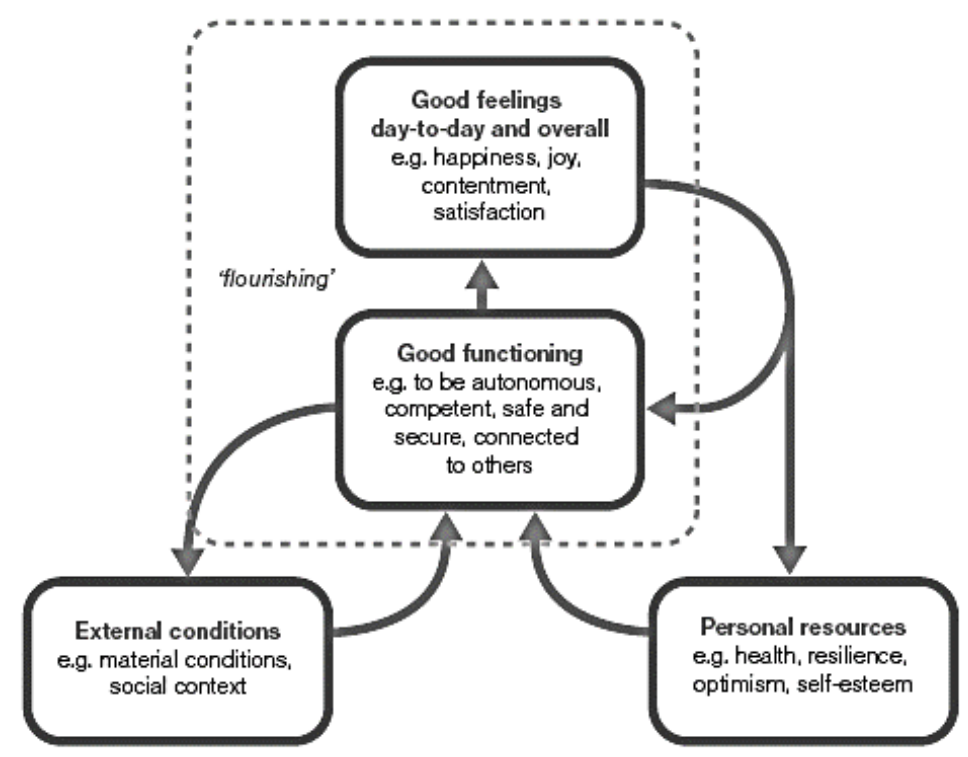

Figure 01. The dynamic model of well-being at work, adapted from Thompson and Marks (2008)

Although there is a personal component to well-being at work, there are also external conditions which might improve $\mathrm{OH}$, and so the CHO's role is essential in this factor.

The $\mathrm{CHO}$ profession can be occupied by many collaborators, and this is one of the dangers and also opportunities. More recently, management in general and marketing management in particular, with Internal marketing approaches, took another view of workers as internal clients and jobs as the first product that organizations offer (Ahmed \& Rafiq, 1995).

Almost 30 years ago, Collins and Payne (1991) argued in the article 'Internal Marketing: A New Perspective for HRM', that there were trends which required human resource managers to have much higher levels of competence and skills, and develop further previous soft mentions of internal marketing.

Internal Marketing Managers might be CHOs, although there is some controversy, with wich we agree, that an internal Marketing view on its one, with no human and psychological tranning is dangerous.

Human resource management's marketing (HRMM) approach is an eclectic designation - as one subsystem of human resource management - is hereby the function organizations need to focus on. It forms the bases for a successful acquiring and retaining of employees by attractively positioning a company on the labor market as well as significantly driving employee satisfaction within a company (Minder \& Balina, 2015).

Authors sum up that (a) the better a company's HRMM approach is in terms of its quality and performance is, the higher is the employees' perception about their employer's organization as well as the overall employees' satisfaction; (b) there is a significant positive relationship between a high quality of HRMM approach and employee satisfaction, and (c) there is a positive relation between a high performance of HRMM and the classification of a company's brand awareness on the labor market as well as a company's classification into an employer of choice is found.

Not that, by defining HRMM approach "as a cross-divisional function of human resource management which influences main process functions of human resource management it is made obvious that HRMM approach is a sub-system of human resource management and not an independent discipline itself" (Minder \& Balina, 2015, p. 196). 
Certainly, there could be an enrichment of different fields of management, but sometimes this might go a little too far "and maybe this 'contamination' between marketing managements tecniques and approachs to human resources management is that case (Hales, 1994).

The author reflects deeply in these implications:

Recently, concepts and techniques developed in other managerial specialisms have begun to make their way into human resource management theory and, to a lesser degree, practice. (...) This is particularly true of the increasing attempt to apply marketing perspectives, concepts and techniques to human resource management (HRM). (...)The discipline of marketing - true, it must be said, to its own nostrums - has for some time been active in advancing its claims beyond its own borders. (p.50)

Nevertheless, Internal marketing provides a somewhat new fresh view on the subject gaining new perspective on the happy-productive worker (Sgroi, 2015) seeing it as an hypothesis to attract and retain talent and really provide an employer branding, setting organizations to more easily build a brand as employers and more easily attract high-quality and motivated talent to the organization.

Additionally, there is a growing interest in brief, low-cost workplace health promotion interventions for wellbeing, which target increasing resilience, mindfulness and positive appraisal (Ross, 2015). Spirituality and transcendent experience are domains addressed by positive psychology (Koltko-Rivera, 2006).

Maslow created the pyramid in 1943 and 1954 and in 1969 amended his model, placing selftranscendence as a motivational step beyond self-actualization (Koltko-Rivera, 2006), and yet many rich and complex construtcs like self-trancendence have been put asid, maybe because they present of too outof-the-box thinkin (Araujo \& Fernandes, 2020).

Overall, The role of a CHO is to Implementing Happiness-Increasing Strategies, among other tasks that might be in CHOS profile like, ergonomics, office space diagnostics, Quality of Working Life, Worklife balance, talent retention and attraction and many others that might be in CHO's profile and Which we discussed when we proposed a Higher Education Post Graduation program in "Organizational Happiness Management" (Araujo \& Fernandes, 2020).

In this paper, we will then adopt and exploratory future method to explore which implications, impacts and consequences might emerge if the organizations of the future hire CHOs.

\section{Problem Statement}

CHO's are emerging as a new, unregulated, with no specific training, future profession. Using Futures Wheel, we aim to brainstorm the possible future consequences of impacts of organizations deciding to hire a Happiness Manager (or create a OH Department).

\section{Research Questions}

Overall, we intend to explore What are the future impacts and consequences of the creation and redesigning of Human resources and marketing management departments and implementing CHO's in the 
future organizations? Particularly, we address 'Which are the consequences of organizations deciding to hire/create a vacancy of CHO's : Chief Happiness officer?’.

\section{Purpose of the Study}

The paper aims to create an exploratory Future Wheel about which are the consequences of Hiring CHOs in future Organizations.

\section{Research Methods}

Traditional research is empirical and present based (Inayatullah, 2006). Futures studies research methods is the systematic study of possible future events and circumstances. The World Futurology Federation is a global non-governmental organization founded in 1973 to promote the development of future studies as an academic discipline. Using several future studies techniques we aim to explore the foreseeable consequences of CHO's in organizations.

Futures studies is the systematic study of possible, probable and preferable futures including, and of the worldviews and myths that underlie each future (Inayatullah, 2007), seeking to "open up the future, moving from the 'likely' future to alternative futures" (p. 6).

According to the author, this type of research is vision oriented, it inspires, it doen't make plans, it attempts to acknowledge the different ways individuals construct the world and it is abstract: through what-if questions and scenarios, the intention is to move out of the present and create the possibility for new futures and it is a vehicle for organizational transformation.

In this research, we choose to implement an exploratory Futures Wheel (FW).

Following suggestions by Bengston (2016) the FW essentially comprises of five phases: (a) Define the Center- "The process begins by carefully defining and describing the change to be examined, called the center, because it is placed in the center of the Futures Wheel” (p.375); (b)Select Participants - An informal or highly exploratory Futures Wheel can be carried out with 4 or 6 participants. In this study we consulted several experts in an informal way, throughout 3 months. Nevertheless, this presents as one limitation of the study, since it would be much more enriched if the participation were formal and structured, and with dozens of participants, involving experts-and non-experts; (c) Identify First-Order Consequences; (d) Identify Second-Order Consequences and so on; (d) Score the Consequences- "Some approaches to the Futures Wheel use the groups to subjectively rate each of the consequences in terms of their importance, uncertainty, and other factors" (p. 377). In this research we chose not to score, since it intends to be a first exploratory step; (e) Analyse and Interpret Results - Participants are debriefed and results are discussed and then a thorough analysis is carried out by the research team with the possibility to use, for example "Inductive thematic analysis to identify broad themes" (p.378), which we used in this paper.

Lastly, we tried to include in the FW, several scenarios, although it is not a pure scenarios methodology. We followed recommendations by Inayatullah (2007), who states that "an excellent scenario approach for organizations is the model developed by Clement Bezoldof the Institute for Alternative Futures. It consists of four scenarios: (1) Business as usual; (2) Best Case; (3) Worst Case; and (4) Outlier 
(based not on a current driver but on emerging issues)" (p.19). In this way, the several ideas within the FW created tried to include this 4 organizational scenarios.

Additionally, our centre question is also a "what-if Question", and according to the author:

What-if Questions: Equally effective in breaking out of conventional categories are 'What-if' questions. These questions challenge one to develop implications of an issue that most would currently think unlikely or absurd. It is useful that there is some element of possibility for the issue, especially if one is concerned with its predictive value. Even so, the most useful issues are those that create new categories of thought. (p. 14)

\section{Findings}

Ten (10) major themes emerged in first-order consequences, those of which are presented in the Wheel, in figure 02 . We discuss briefly each theme.

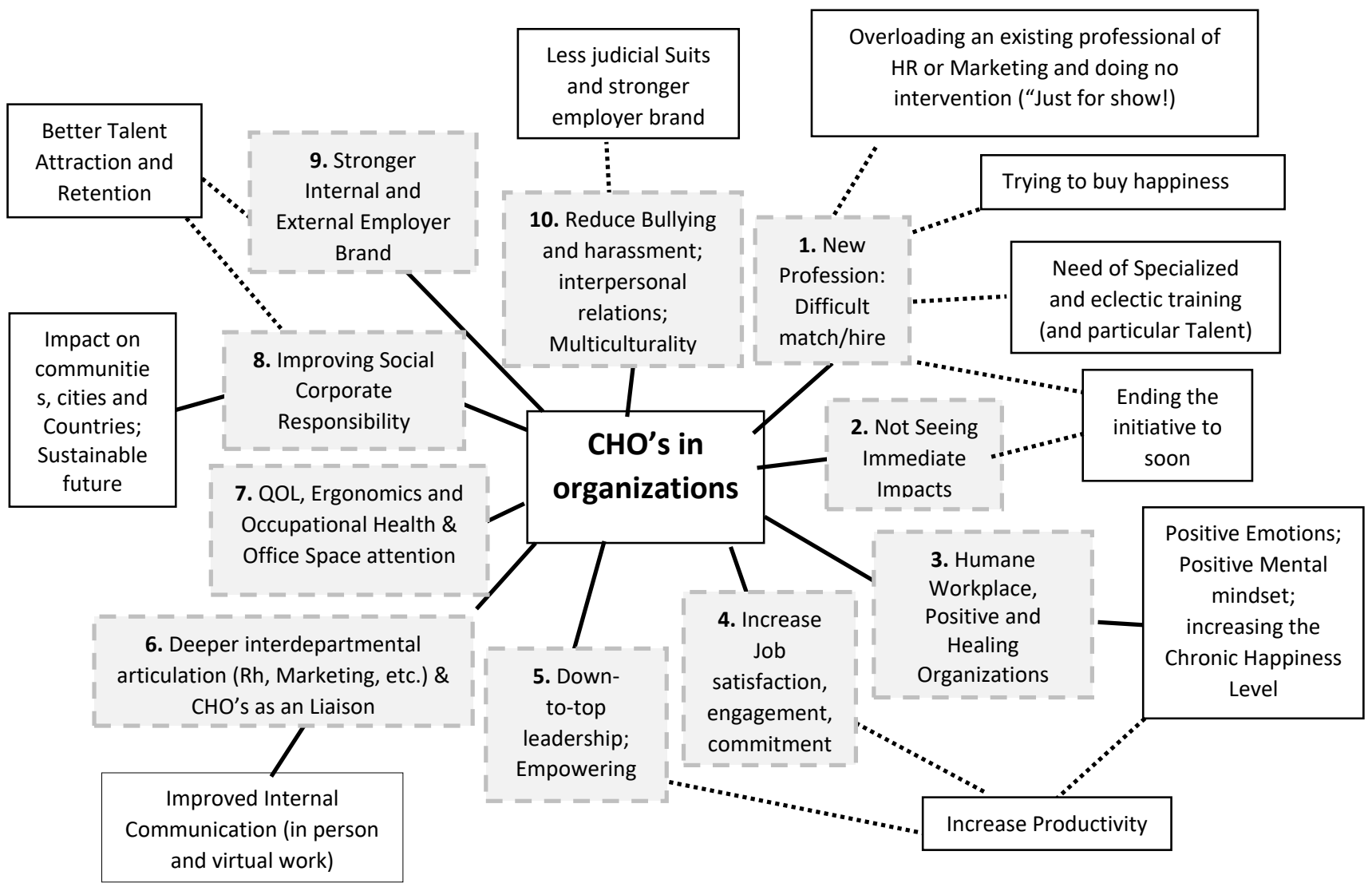

Figure 02. Future Wheel on Consequences if organizations hire a CHO-Chief Happiness Officer Notes:

First Line consequences

Second Line Consequences 


\section{Theme 1. 'New Profession: Difficult match/hire'}

Regarding Theme 1. 'New Profession: Difficult match/hire', we addresses this issue deeply on another research (Araujo \& Fernandes, 2020). But, overall, in spite the fact that the interdisciplinary richness might be an advantage, on the other hand it might be problem or a challenge, since there is no offer or proper training (particularly in Higher education). Many simplistic training offers of a few hours, selling "happiness certification" for expensive payments have emerged worldwide, which is a danger step.

The 'trying do buy happiness' aspect relates to some of our experience in the field, and many managers and leaders believing that implement Happiness-Strategies and well-being at work intervention is all about simple and effective compensation and benefits package. This is one of the major myths we have to end, and, once again a dangerous assumption.

Still in theme 1., in a second-order consequence, the Media effect or the 'Just for show Effect' is listed: Unfortunately, the 'Just for show' Effect might happen with these new professions, that might causa media impact (it is our opinion that this trend is happening in Portugal), overloading an existing professional of HR or Marketing and doing no scientific intervention at all ("Just for show!' and for usage as an external marketing strategy).

Because of that, there is some resistance to that title/designation of $\mathrm{CHO}$ and many companies use other designations, for example, Head of Employee Wellbeing, Employee Care Initiatives, Organizational Psychologist, Occupational health Department, amongst others. It is not the aim of this paper to explore this 'terminology war' and, furthermore, we believe is has much to do with cultural and historical aspects of each country, nevertheless, it appears to be a worthwhile debate, ins contructivist days, where narratives and storytelling are central.

\section{Theme 2. 'Not Seeing Immediate Impacts'}

In number 2. emerges 'Not Seeing Immediate Impacts', which is a common problem in human and social sciences overall, since changing behaviours and attitudes is a long-term intervention. The risk of killing the idea to soon, exists, since organizations might think it is a waste of money, in spite of strong research results pointing that $\mathrm{OH}$ interventions work. According to Lyubomirsky et al. (2005) HappinessIncreasing strategies interventions have showed to be effective in many research in the last 30 years, and they "Might be divided into one or more of the three categories of activity outlined earlier: behavioral (e.g., “spend more time socializing”), cognitive (e.g., "become present oriented”), and volitional (e.g., "get better organized and plan things out") (p. 122). So, in this way a CHO is a strategist and intentionally plans and implements happiness interventions in organizations.

\section{Theme 3. Humane Workplace, Positive and Healing Organizations}

The CHO helping create a Humane and positive organizational climate is a basic deduction. But, futures studies aims higher and farther into the future. We all know the deep latent and psychological functions of work and jobs, for example, feelings of belonging, time structure, routines, establishing relations, feeling recognized, contributing to society, among others (Araujo, 2015) and so belonging to an Humane Workplace, and a Positive and Healing Organization might really Heal. This notion of healing organization is a fascinating one, in our opinion, taking even futher the idea of Learning organizations by 
Peter Senge, Inayatullah (2002) unveils that "The a healing organisation is the second half of a learning organisation" (p. 20).

In our opinion, the healing organization idea might cross the ideas of purpose, meaning and transcendence that we also approached, and hiring a $\mathrm{CHO}$ might be at the center of it all.

Theme 4. Increase Job satisfaction, engagement, Organizational commitment \& Theme 5. Down-to-top leadership; Empowering

Themes 4 and 5 are interconnect, since Down-to-top leadership and Empowering practices have long proved to promote job satisfaction, engagement and commitment (Ahmed \& Rafiq, 1995). On the other hand, the best practice in developing a credible and competitive EVP is to be responsive to the expectations of the people (Bell, 2005) and that goes with all major arguments for empowerment in the work place. Even internal marketing drwas clearly from human resources practices and apllies empowerment-developed strategies for engagement and external marketing success, and overall increased productivity (Ahmed \& Rafiq, 1995).

Another interesting and out-of-the-box contribute, is for example, the book "The dream Manager", which is business parable about how companies can achieve remarkable results by helping their employees fulfill their dreams by Kelly (2007). With some practical and real life examples from his life as an organizational consultant, Kelly shows us that listening to needs of workers and their dreams, is an empowering and cheap way to fulfil dreams (not that the dream manager does not work with money or extrinsic factors, but helps people pursue their dream. For exmplo, a worker who always wanted to study more, learn a skill, improve an aspect of their job, etc.).

\section{Theme 6. Deeper interdepartmental articulation (Rh, Marketing, etc.) \& CHO's as an Liaison}

Deeper interdepartmental articulation (Rh, Marketing, etc) since, finnaly, organizations might have a proper and adequate and official Liaison between departments, promoting Internal communication and overall, 'Environmental clarity'. This is one of the major areas of interventions from internal marketing perspective and, in our opinion, little explored by human resources department because they are usuaaly overloaded and internal communication, although, frequently diagnosed as an are of intervention is also frequently postponed.

Theme 7. QWL, Ergonomics and Occupational Health \& Office Space attention \& Theme 8. Improving Social Corporate Responsibility

QWL evolved a lot since the beginning of the construct (Fernandes, 1996) growing from simple human rights views, to organizational climate, work-life balance, job design, equality, into more complex subjects like stress management and overall healthy workplaces.

In general, Ergonomics and office space design has never been a priority for many organizations, but now that organizations are becoming increasingly aware of talent attraction and retention, employer branding and Social corporate responsibility since Organizations Social Corporate Responsibility "seriously and sincerely will be contributing to a more positive attractiveness profile" (Bell, 2005, p. 3).

Office space design is also a way to promote happiness and well-being instead of just seeing it as a mere place of work and so, multidisciplinary approaches do Happy offices is needed and recommended 
(Martinho, 2020) As we stated in others papers (Araujo \& Fernandes, 2020) Occupational Health Psychology as almost undoubtable lost their opportunity to become the CHO's be excellence but occupational health in general, is in its self, a multidisciplintry field which CHOs must master.

\section{Theme 9. Stronger Internal and External Employer Brand}

Organizational difficulties in attracting talent should alert to the need of employer brands "to present characteristics differentiating them from competitors. Employer branding is a fusion area between human resources and marketing, which aims to build an organization's reputation as a great place to work. The future of organizations depends on the quality of the workforce they can attract" (Noutel et al., 2020, p. 282). EVP- Employee Value Proposition is closely connected with Employer branding and the best EVPs flow from strong company values, principles and strategic objectives (Bell, 2005). To attract talent, organizations:

must become attractive to potential employees, by clearly defining their attributes, in comparison to their competitors, creating an EVP which encompasses everything they offer as employers, from the global level compensation, to the work environment. A new big challenge is the generational hodgepodge and the fact that they have to attract an increasing number of millennials, with job expectations quite different from other generations. (Noutel et al., 2020, p. 283)

Although EVP is an area where HR can make a key contribution and establish a stronger strategic and added-value role, rather than remaining in the safe harbor of transactional expertise (Bell, 2005) we believe the $\mathrm{CHO}$ is the adequate future professional to intervened intentionally and strategically in building a strong employer brand and EVP.

\section{Theme 10. Reduce Bullying and harassment; interpersonal relations and multiculturality}

Better interpersonal relations, improved relatedness and intrinsically reasons for working there go hand in hand with many views on human development (Ryan \& Deci, 2000) and even on recent motivation at work theories, with intrinsic motivation, purpose, mastery and relatedness assuming a major role for workers of the future (Pink, 2011).

Workplace Bullying or mobbing, moral, religious or sexual harassment, discrimination and other phenomena can also be addressed by CHOs, who might promote multiculturality organizations and privilege respect - diversity and inclusion (Bell, 2005).

\section{Conclusion}

Lyubomirsky et al. (2005) speak of finding the chronic happiness level and for that they "focus on three primary types of factors that they believe causally affects the chronic happiness level: set point, life circumstances, and intentional activity" (p. 111). We defend that CHOs act directly helping workers master the intentional activity part implementing Happiness-Strategies and well-being at work intervention.

The need to transition to a new economics more humane, peaceful and equitable is undeniable, and human species need to go deeper in to Mindful Employer and mindful Leaders and Worthwhile work. 
In 2015, world leaders agreed to 17 goals for a better world by 2030 and the 8 th is 'decent work and economic growth', with ILO-International Work Organization redefining at the same time the decent work concept.

And so, in this paper we presented a first exploratory Futures Wheel to star introducing to organizations worldwide that CHO's represent an opportunity to rewire organizations and turn them into the future.

Regarding limitations and future research, it is important to reflect that ideally, the futures wheel should include formal and structured participation, and with dozens of participants, involving experts-and non-experts. On the other hand, one might reflect about subjectivity and trustworthiness issues. Nevertheless, as Inayatullah (2006) reflects about future studies: "We cannot and should not remove ourselves from the research environment. Rather, we should be epistemologically clean, stating up front what we perceive to be our value commitments. Thus, ethics is increasingly playing an important role in imagining and analysing alternative futures" (p. 11).

I am a researcher and have been a happiness manager almost all my career as an organizational and occupational health Psychologist, as an internal marketing manager, and a Well-being at work consultant and Professor and several other designations and, simultaneously a researcher: I never had a professional category as a CHO's, because many organizations don't even know what that is. So, I believe it was relevant to make this brief consideration in order to keep the idea that in future methods, we do not remove ourselves from the research but we participate, with ethics and trustworthiness awareness.

The Futures approach is about using the future to rethink and eventually re-create today, it engages professionals and citizens in efforts to create anticipatory democratic systems and Agency is enhanced and ideally more sustainable futures created (Inayatullah, 2020).

However, in these storytelling-centered days, I find myself going to the past for a moment: It is strange and at the same time interesting to think about the story we are telling and the history we are writing. It comes to mind Elton Mayo and Mary Parker Follet, and the Human Relations movement at work, and , curiously, almost 100 years after the Hawthorne experiments (1924-1932).

At the core of human relations theory are these six basic propositions:

(i) A focus on people, rather than upon machines or economics; (ii) The organizational environment is not an organized social context; (iii)Human relations are important in motivating people;(iv) Motivation depends upon teamwork, requiring co-ordination and cooperation of individuals involved; (v) Human relations within teams must fulfill both individual and organizational objectives simultaneously; (vi) Individuals and organizations desire efficiency by achieving maximum results with minimum inputs. (The Business Professor, 2020, para 5)

Does not it seems that this 6 propositions apply perfectly to future CHOs? Are we 100 years later fighting for the same thing with different names?

Was Elton Mayo and Mary Follet, the First CHOs? Or Henry Ford For example?

Henry Ford had sociological department (around 1920), created because "Factory work was boring, monotonous, dangerous, and it didn’t pay well at all” (Ballaban, 2014, para 9) but the search for happiness 
of all works was in his mind, implementing on of the biggest raises in the history of industry. Nonetheless, his department was also a kind of secret police to be used by Ford as we wished and:

“- To qualify for his doubled salary, the worker had to be thrifty and continent. He had to keep his home neat and his children healthy, and, if he were below the age of twenty-two, to be married." (para. 12); (...)

- What started out as a team of 50 "Investigators" eventually morphed into a team of 200 people who probed every aspect of their employees lives. And I mean every aspect. [morality, English, cleanead houses, etc); (para 16); (...)

- $\quad$ But if you didn't live up to the standards of Henry Ford and his Investigators, you were doomed. If you didn't toe the line, you were initially blacklisted, and your prospects for promotion and advancement would vanish (para. 20)

These brief final considerations focus on Ethics of CHOs. All this search for happiness and relating work with other areas of human life, might be ethically in danger.

In case of Ford's sociological department, Later on "it was replaced with something far more sinister. As the demand grew for unions, nastier spies and thugs found themselves under corporate employ" (para 25).

So...if you are not happy at work by you still execute or job perfectly and your aim is only a normative commitment, a transactional view, where you do the task and get paid... what will happen to you? What will happen to unhappy people at work that are ok with it? People whose view of work was always as a sacrifice and who lived on a family-centered societ, for example, the baby boomers generation, that differs so much from Millenials or Z generation?!

For example, many countries are implementing data-driven technology that measures smiles and moral attitude of citizens, through facial recognition and reading emotions, and that information might be used and abused. Ethical implications of $\mathrm{CHO}$ professions are huge, and very similar to old debates for example, within the practice of Organizational psychology, where both the organization and the worker are the psychologist clients.

The debate does not end here and it is our belief that this reframing of old professions in this new emerging profession as Chief Happiness Officers, might reveal it self to be a way to impact all areas all life and not only the working life and so, we believe, as many others, that the pursuit of happiness is always a good thing...:

Is the pursuit of happiness merely a bourgeois concern, a symptom of Western comfort and selfcenteredness, factor that has no real impact on psychological adjustment and adaptation? The empirical evidence suggests that this is not the case. Indeed, a number of researchers and thinkers have argued that the ability to be happy and contented with life is a central criterion of adaptation and positive mental health (e.g., Diener, 1984; Jahoda, 1958; Taylor \& Brown, 1988)'”. (as cited in Lyubomirsky et al., 2005, p. 111) 


\section{Acknowledgments}

The author thanks for the costs help regarding travelling arrangements and inscription fee, necessary to present this research in the $11^{\text {Th }}$ ICEEPSY, by IPAM-Portuguese Institute of Administration and

Marketing and European University of Portugal.

\section{References}

Ahmed, P. K., \& Rafiq, M. (1995). Internal Marketing: Tools and Concepts for customer-focused Management. Taylor \& Francis.

Araújo, P. (2015). Multiplasticity: A Grounded Theory on the Adaptation to Anemployment (Doctoral Thesis), Faculdade de Psicologia e de Ciências da Educação da Universidade do Porto.

Araújo, P., \& Fernandes (2020). Training 'cho's' chief happiness officers: a higher education course design challenge. EPICEEPSY, 1

Ballaban, M. (2014). When Henry Ford's Benevolent Secret Police Ruled His Workers. https://jalopnik.com/when-henry-fords-benevolent-secret-police-ruled-his-wo-1549625731

Bell, A. (2005). The employee value proposition redefined. Strategic HR Review, 4(4), 3-3. https://doi.org/10.1108/14754390580000792

Bengston, D. N. (2016). The Futures Wheel: a method for exploring the implications of social-ecological change. Society \& Natural Resources, 29(3), 374-379.

Collins, B., \& Payne, A. (1991). Internal marketing: a new perspective for HRM. European Management Journal, 9(3), 261-270.

Kelly, M. (2007). The Dream Manager. Hyperion Editions

Fernandes, E. (1996). Qualidade de vida no trabalho: como medir para melhorar [Quality of Working Life: How to measure to improve]. Casa da Qualidade.

Fisher, C. D. (2010). Happiness at Work. International Journal of Management Reviews, 12(4), 384-412. https://doi.org/10.1111/j.1468-2370.2009.00270.x

Hales, C. (1994). "Internal Marketing" As an Approach to Human Resource Management: A New Perspective Or A Metaphor Too Far? Human Resource Management Journal, 5(1), 50-71. https://doi.org/10.1111/j.1748-8583.1994.tb00359.x

Koltko-Rivera, M. (2006). Rediscovering the later version of Maslow's hierarchy of needs: Selftranscendence and opportunities for theory, research, and unificatio. Review of General Psychology, 10(4), 302-317.

Inayatullah, S. (2002). The Learning and Healing organization. EEP Executive Excelence. http://www.metafuture.org/library1/EmergingIssues/Learning-and-Healing-OrganizationExecutive-Excellence-2002.pdf

Inayatullah, S. (2006). Anticipatory action learning: Theory and practice. Futures, 38(6), 656-666. https://doi.org/10.1016/j.futures.2005.10.003

Inayatullah, S. (2007). Questioning the Future: Methods and Tools for Organizational and Societal Transformation. Tamkang University.

Inayatullah, S. (2020). Conspiring to destroy or to create better futures. UNESCO Futures of Education Ideas $L A B$. https://en.unesco.org/futuresofeducation/ideas-lab/inayatullah-conspiracy-theoriesdestroy-or-create-better-futures

Lyubomirsky, S., Sheldon, K. M., \& Schkade, D. (2005). Pursuing happiness: The architecture of sustainable change. Review of general psychology, 9(2), 111-131.

Martinho, S. (2020). Happy office checklist: Creating and Internal Marketing Instrumento for Organizational Happiness-Centered Office Spaces [Happy office checklist: criação de um instrumento de marketing Interno para o escritório do futuro centrado Na felicidade organizacional] (Master's Thesis). Portuguese Institute of Administration and Marketing.

Minder, S., \& Balina, S. (2015). Human Resource Management's Marketing Approach and Its Contribution Towards Employee-Satisfaction. Expert Journal of Business and Management, 3(2), 194-204. 
Noutel, R., Araújo, P., Fernandes, R., \& Arriscado, P. (2020). An Employer Branding Strategy: Developing A Talent Atraction Model Through Action Research. IN Elisabete Pinto da Costa, Maria do Rosario Anjos, Miroslaw Przygoda (Eds), Economic and Social Development. Varazdin Development and Entrepreneurship Agency. University North \& Lusofona University of Porto. https://www.esd-conference.com/upload/book_of_proceedings/Book_of_Proceedings_esdPorto2020_Online.pdf

Pink, D. (2011). Drive: The suprising truth about what motivates us. Penguin Books.

Ross, S. (2015). Positive mental training: efficacy, experience and underlying mechanisms of a health promotion intervention for resilience and wellbeing in the workplace (Doctoral Dissertation). University of Edinburgh.

Ryan, R. M., \& Deci, E. L. (2000). Self-determination theory and the facilitation of intrinsic motivation, social development, and well-being. American Psychologist, 55(1), 68-78. https://doi.org/10.1037/0003-066X.55.1.68

Sgroi, D. (2015). Happiness and productivity: Understanding the happy-productive worker. Global Perspectives Series, 4

Thompson, S., \& Marks, N. (2008). Measuring well-being in policy: issues and applications. https://b.3cdn.net/nefoundation/575659b4f333001669_ohm6iiogp.pdf

The Business Professor (2020). Human Relations Theory of Management. Last accessed August 14, 2020. Retrieved from https://thebusinessprofessor.com/lesson/human-relations-theory-of-management/ 